\title{
Natural Dyes from Mortiño (Vaccinium floribundum) as Sensitizers in Solar Cells
}

\author{
Miguel A. Taco-Ugsha ${ }^{1,2}$, Cristian P. Santacruz ${ }^{2, *}$ and Patricio J. Espinoza-Montero ${ }^{1, *(\text { (i) }}$ \\ 1 Escuela de Ciencias Químicas, Pontificia Universidad Católica del Ecuador, Avenida 12 de Octubre y Roca, \\ Apartado postal: 17012184 Quito, Ecuador; migueat@yahoo.es \\ 2 Departamento de Física, Escuela Politécnica Nacional, Ladrón de Guevara E11-253, \\ P.O. Box 17-01-2759 Quito, Ecuador \\ * Correspondence: cristian.santacruz@epn.edu.ec (C.P.S.); pespinoza646@puce.edu.ec (P.J.E.-M.); \\ Tel.: +593-2299-1700 (ext. 1929) (P.J.E.-M.)
}

Received: 23 December 2019; Accepted: 6 February 2020; Published: 11 February 2020

\begin{abstract}
Photovoltaic energy presents environmental advantages; however, these advantages are limited by the cost of manufacturing solar cells and in many cases, scarce or dangerous materials are incorporated. Therefore, the use of natural dyes from mortiño (Vaccinium floribundum) as sensitizers in solar cells is proposed. The dyes were extracted by maceration in acidified methanol $(\mathrm{HCl}$, citric acid and trifluoroacetic acid TFA) and were characterized by High-Performance Liquid Chromatography (HPLC), Thin-Layer Chromatography (TLC) and spectrometric methods (UV-Vis, IR and MS-MALDI). The construction and characterization of cells were in standard conditions. The study confirms that pigments in mortiño are flavonoids of the anthocyanidin group as: cyanidin-3-galactoside, and cyanidin-3-arabinoside. The efficiency of solar cells was between $0.18-0.26 \%$; the extraction with TFA in methanol leads to the best performance. Although they have low power conversion efficiency, mortiño dyes could be an alternative to artificial sensitizers for solar cell technologies because they are harmless and abundant substances.
\end{abstract}

Keywords: anthocyanins; dye; efficiency; mortiño; solar cells; sensitizer

\section{Introduction}

According to the International Energy Agency (IEA) [1], the energy generation implicates $68 \%$ of global greenhouse gases (GHG), where the principal source corresponds to non-renewable resources. Clean energies like solar energy have been developed to decrease GHG emissions. Solar cells could incorporate scarce and hazardous materials [2]. Also, GHG can be emitted in steps of many production materials e.g., poly-crystalline and mono-crystalline silicon [3,4]. Dye Sensitized Solar Cells (DSSC) have emerged as an alternative to conventionally solar cells because they offer some advantages: (a) Low-light performance, DSSC works in a wide array of lighting conditions, without suffering from angular dependence of sunlight or light. (b) Optimized performance, DSSC materials and dyes can be tuned for optimization in a variety of lighting conditions making it suitable for indoor applications and outdoor applications. (c) Higher temperature performance, DSSC efficiency does not degrade with increased temperature, meaning it possible to continue to efficiently harvest energy in direct sunlight. (d) Low energy manufacturing process, DSSC are manufactured using low-energy consumption, high-efficiency, and roll-to-roll manufacturing technique. (e) Ecologically friendly, DSSC uses inexpensive and eco-friendly nano-materials without concern about shortage of resources. $(f)$ Variety of substrates, DSSC is produced on a thin film, flexible, robust, plastic substrate. DSSC can also be applied to metal and glass substrates. $(g$ ) Versatile product integration, DSSC indoor modules are highly flexible, durable and lightweight [5-7]. However, some disadvantages of the DSSC must be 
taken into account, such as: (a) the use of liquid electrolyte could affect the stability of the cell when there are temperature changes (the electrolyte can freeze at low temperatures and can expand at high temperatures). In addition, electrolyte solutions usually contain volatile organic compounds, solvents that must be carefully sealed, because they are hazardous to human health and environment. This, together with the fact that solvents impregnate plastics, has prevented large-scale outdoor application and integration in a flexible structure. (b) The materials for the construction of this type of cell could become very expensive, e.g., platinum (catalyst), ruthenium (dye) and glass or plastic conductive (contact), etc. (c) [7].

On the other hand, the sensitizer is a fundamental variable in any DSSC and its characteristics respond to DSSC performance. Desirable requirements of the sensitizer are: It generates an efficient injection of electrons toward the semiconductor conduction band, provides functional groups for chelating to the semiconductor, and has a high molar extinction coefficient [8,9]. Natural dyes are attractive alternatives to synthetic sensitizers due to their low cost, facile obtention, abundance, and being harmlessness to the environment $[10,11]$. Among natural pigments, anthocyanins have remarkable characteristics to incorporate in solar cells [12,13]. In order to improve the efficiency of DSSC, anthocyanins were combined with graphene as a co-adsorbent to improve charge transferring at the photoanode [14], organic acids [13], and others additives to avoid dye agglomerates [15]. Applications of anthocyanins from natural sources have been studied, however, there is not enough information about the characterization of the pigment from the natural dyes used $[12,15,16]$.

Mortiño is an endemic fruit of the Andes that grows widely in moorland heights between 2800 and $4000 \mathrm{~m}$ above sea level [17,18]; in Ecuador, this fruit is part of food heritage [19]. It is a great source of polyphenols and flavonoids such as anthocyanins derived from cyanidin and delphinidin [20]. Mortiño showed antioxidant, anti-inflammatory and adipogenesis inhibiting properties due to a high content of available photoactive components [21], also it has showed applications in the synthesis of photocatalytic nanocomposites [22]. Anthocyanins have several hydroxyl groups that bind with $\mathrm{TiO}_{2}$ nanoparticles via metal complexation, and it has been shown that excited anthocyanin molecules are able to inject electrons into the conduction band of $\mathrm{TiO}_{2}$ very efficiently [23,24]. Besides, several authors have demonstrated that the mixture of natural dyes could improve the energy conversion efficiency of natural DSSC [24-26]. According to Strauch et al., there is significant variation in the anthocyanin composition in the population of red cabbage, therefore, the plausible anthocyanin content in mortiño fruit is different from others fruits and flowers studied previously [27]. Finally, it is expected to obtain devices that provide good photovoltaic characteristics and lower environmental impact, as a result of the application of pigments from mortiño, for sensitizers in solar cells. This work focuses on the characterization of pigments from mortiño (Vaccinium floribundum) extracted with different acids and the evaluation as natural sensitizers in solar cells.

\section{Materials and Methods}

\subsection{Reagents and Materials}

Samples of mortiño ( $V$. floribundum) were purchased in popular markets of Quito; fresh fruit was selected and washed with distilled water. The samples were oven-dried at $50{ }^{\circ} \mathrm{C}$ during $72 \mathrm{~h}$ and grinded with a mortar. This material was collected and stored in polyethylene containers at $-20^{\circ} \mathrm{C}$.

Methanol (99.5\%), trifluoroacetic acid (TFA, 99.8\%), ethyl acetate $(99.8 \%)$, and acetone $(99 \%)$ ACS grade were purchased from J.T. Baker (Pensilvania, United States of America USA). Other ACS grade reagents such as: fuming hydrochloric acid (37\%), formic acid (98-100\%), phosphoric acid $(85 \%)$, sodium hydroxide, citric acid and 2-propanol ( $\geq 99.8 \%)$, methanol, and acetonitrile (HPLC) were obtained from Merck (Damrstatd, Germany). Cyanidia-3-glucoside standard ( $>97 \%$ ) was obtained from Phytoplan (Heidelberg, Germany). C18 cartridges (Cromabond ${ }^{\circledR}$ C18ec, $500 \mathrm{mg} / 6 \mathrm{~mL}$ ) were obtained from Mancherey Nagel (Durën, Germany). Silica gel TLC chromatographic plates with fluorescence indicator $(10 \times 10 \mathrm{~cm}, 254 \mathrm{~nm})$ and cyanidinium chloride $(\geq 95 \%)$ standard were purchased 
from Sigma Aldrich (St. Louis, MO, USA). The $\alpha$-cyano-4-hydroxycinnamic acid matrix (>99.0\%) for MALDI was obtained from Fluka (Buch, Switzerland).

For DSSC construction, a transparent conductor substrate of fluorinated-doped tin dioxide (FTO) of $2.2 \mathrm{~mm}, 15 \Omega / \mathrm{sq}$; nanoparticulate $\mathrm{TiO}_{2}$ paste (D/SP); electrolyte solution (Iodolyte AN-50, $50 \mathrm{Mm}$ ); Pt precursor (Platisol T); and thermoplastic sheet (Meltonix $60 \mu \mathrm{m}$ SX 1170-60PF) were purchased from Solaronix (Aubonne, Switzerland).

\subsection{Dye Extraction and Characterization}

Mortiño dyes were extracted by maceration, using methanol acidified with $\mathrm{HCl}(0.01 \% v / v)$, citric acid $(2.5 \% w / v)$ and trifluoroacetic acid (TFA, 3\% v/v). Mortiño/methanol ratio was 1:4, the mixture was vacuum filtered (grade 2 filter paper), and the solvent was removed under reduced pressure (rotavapor IKA RV 10) at $35^{\circ} \mathrm{C}$ and 200 mbar. The concentrates were centrifuged, and their supernatants were filtered on a membrane $(0.5 \mu \mathrm{m})$. The extracts were stored at $-20^{\circ} \mathrm{C}$. The amount of monomeric anthocyanins in extracts, as cyanidin-3-glucoside (Cy-3-gl), was determined by the $\mathrm{pH}$ differential method according to [28]. The characterization of dyes and dye/ $\mathrm{TiO}_{2}$ (photoanode) was done with UV-Vis spectrophotometer (Varian Cary 50 Bio from Agilent Technologies, California, USA); acidified methanol and $\mathrm{TiO}_{2} / \mathrm{FTO}$ were used as blank respectively. Mortiño extracts were purified by solid phase extraction (SPE) for IR and HPLC analysis with octadecylsilane cartridges (C18), according to [29]. Purified anthocyanins were analyzed with IR spectrophotometer (FT-IR, Perkin Elmer Spectrum One, Massachusetts, USA) using $50 \mu \mathrm{L}$ of extract that was dried on anhydrous $\mathrm{KBr}$ discs $\left(40{ }^{\circ} \mathrm{C}, 0.5 \mathrm{~h}\right)$. Purified dyes were analyzed by a methodology proposed by [30] with HPLC-Diode Array Detector (DAD, Dionex ultimate 3000) provided with a C18 column (Acclaim ${ }^{\circledR} 300,3 \mu \mathrm{m} ; 4.6 \times 150 \mathrm{~mm}$ ). Binary mobile phase of acetonitrile (A) and $\mathrm{H}_{3} \mathrm{PO}_{4} 4 \%$ (B) was used; the elution gradient was $6 \% \mathrm{~A}-94 \% \mathrm{~B}$ (0-6 min); 25\% A-75\% B (10-65 min), and 6\% A-94\% B (65-70 min).

For the separation TLC, a chamber with a ternary mobile phase of 1-butanol, formic acid and water (BAW) in a volume ratio of 60:10:15 was conditioned for $2 \mathrm{~h}$. Extracts seeding was carried out with an atomizer (Camag Liomat 5-WinCats) on silica gel plates. After separation ( $~ 1.5 \mathrm{~h})$, solvents were evaporated at room temperature (RT). The fractions were recovered with formic acid $(20 \% v / v)$ and centrifuged at $5000 \mathrm{rpm}$ for $15 \mathrm{~min}$; the supernatants were filtered on a $0.2 \mu \mathrm{m}$ pore. The filtrates were combined with $10 \mathrm{mg} / \mathrm{mL}$ of $\alpha$-cyano-4-hydroxycinnamic acid (CHCA) matrix dissolved in acetonitrile with $0.01 \%$ TFA $v / v(10: 40)$, these were deposited on stainless steel plates and dried for MALDI-Tof analysis. The spectrometer was built in the Physics Department of Escuela Politécnica Nacional (EPN, Quito, Ecuador) using the guidelines of [31]. A 337-nm nitrogen laser ionization (Spectra-Physics 337201-001) was used, and the signals were recorded in an oscilloscope (Tektronix TDS 5052). The determinations resulted from the average of 20 spectra, each one obtained by 10 pulses.

\subsection{DSSC Construction and Characterization}

The deposition of anatase $\mathrm{TiO}_{2}$ paste on FTO was carried out with screen printing using SEFAR PET 1500 mesh with areas of $25 \mathrm{~mm}^{2}$. The $\mathrm{TiO}_{2}$ paste layer on the FTO substrate was homogenized by "spin coating" (Laurell WS-650HZB-23-223NPPB0) for $25 \mathrm{~s}$ at $2000 \mathrm{rpm}$. The deposit was dried by gradually increasing the temperature to $120^{\circ} \mathrm{C}$ for 10 minutes on a heating plate (Thermo Scientific CIMAREC, Pennsylvania-USA) and cooled at RT. With this procedure, three layers of paste were placed on FTO and sintered on a plate at $450{ }^{\circ} \mathrm{C}$ for $30 \mathrm{~min}$. The $\mathrm{FTO} / \mathrm{TiO}_{2}$ plates (photoanode) were each immersed in $5 \mathrm{~mL}$ of mortiño methanolic extract in closed glass containers and in the dark for $72 \mathrm{~h}$, then the non-adsorbed dye was removed with deionized water and dried at RT. The counter electrode was prepared with a Pt precursor deposited on the FTO with a brush and then sintered at $475{ }^{\circ} \mathrm{C}$ on a hotplate for $30 \mathrm{~min}$. The photoanode and the counter electrode were assembled using a polymeric sheet frame heating at $\approx 120^{\circ} \mathrm{C}$ with a homemade iron. The electrolyte was incorporated by vacuum with syringe through a hole in the counter electrode. Finally, the hole was covered with a piece of hot melt polymer and a piece of glass by heating at $120^{\circ} \mathrm{C}$ with a soldering iron. The cells were 
illuminated under conditions of $1000 \mathrm{~W} / \mathrm{m}^{2}$ and AM 1.5 by means of a solar simulator and coupled to a source unit of measurement (KEITHLEY 2400).

\section{Results and Discussions}

\subsection{Monomeric Anthocyanin Content}

The amount of anthocyanins was quantified in mortiño fruit and their methanolic extracts. In fruit, the content as $\mathrm{mg} C \mathrm{C}-3-\mathrm{gl} / 100 \mathrm{~g}$ was $144 \pm 7$, being lower in comparison with results previously reported [20,21]. During the extraction process, methanol acidulated with TFA was the medium with a major content of anthocyanins of $(575 \pm 26) \mu \mathrm{g} \mathrm{Cy}-3-\mathrm{gl} / \mathrm{mL}$, followed by $\mathrm{HCl}(444 \pm 22) \mu \mathrm{g} \mathrm{Cy}-3-\mathrm{gl} / \mathrm{mL}$ and citric acid $(329 \pm 18) \mu \mathrm{g}$ Cy-3-gl/mL. Differences in the content of anthocyanins evidenced the extraction capacity of distinct acidic media. Variations in chemical properties of the acids would influence the polarity and acidity character of extractant medium. In addition, the $\mathrm{pH}$ values in the extracts were about 3 , which is appropriate since the acidic medium tends to stabilize anthocyanins as flavylium form [29]. It is also convenient because a too-acidic medium ( $\mathrm{pH} 1$ ) would damage $\mathrm{TiO}_{2}$ deposit [16].

\subsection{UV-VIS Spectroscopy}

Absorption spectra of mortiño methanolic extracts acidified with $\mathrm{HCl}$, citric acid and TFA are shown in Figure 1a; these exhibit two absorption bands $\left(\lambda_{\max }\right)$ at 280 and $530 \mathrm{~nm}$ which are characteristic of anthocyanins. The band absorption with $\lambda_{\max }$ at $530 \mathrm{~nm}$ is assigned to derived cyanidins such as 3-glucoside and 3-galactoside dissolved in methanol acidified with $\mathrm{HCl}$, as previously reported $[28,32,33]$. However, the possibility of finding anthocyanins with different $\lambda_{\max }$ that overlap and contribute to this band must be considered; e.g., anthocyanidins can also present absorption into this wavelength portion [34]. The absorption interval shown in the visible range between $47550 \mathrm{~nm}$ allows the harvesting photons, which is necessary for sensitization in a solar cell. Absorption spectra of the dyes adsorbed on $\mathrm{TiO}_{2}$ are shown in Figure $1 \mathrm{~b}$; their $\lambda$ max are displaced between 6 and $11 \mathrm{~nm}$ in comparison to the absorption band of the dyes alone. This hypsochromic effect shows an interaction between the pigment and the semiconductor; it corresponds to changes in the energy levels in the pigments (HOMO and LUMO), which affect the band gap of $\mathrm{TiO}_{2}$. The displacements of $\lambda_{\max }$ are comparable to previous reports where anthocyanin sensitizers were used [35,36], this corroborates the chemical adsorption of anthocyanin on $\mathrm{TiO}_{2}[36]$.
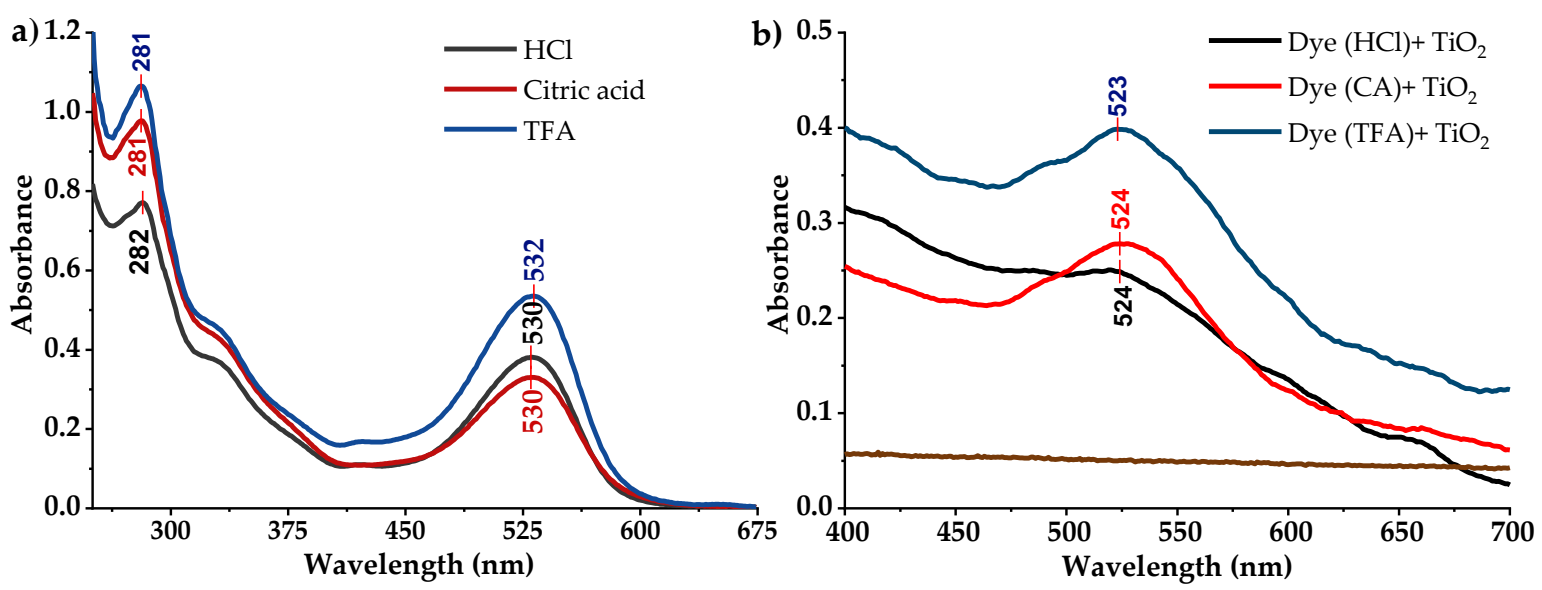

Figure 1. UV-Vis spectra. (a) Mortiño pigments diluted in methanol (DF = 100). (b) Pigments adsorbed on $\mathrm{TiO}_{2} / \mathrm{FTO}$ (counter electrode). 


\subsection{Infrared Spectroscopy}

The infrared spectra of the anthocyanin dyes (Figure 2) showed important bands in the fingerprint region $\left(600-1400 \mathrm{~cm}^{-1}\right)$, an intense absorption in $1030 \mathrm{~cm}^{-1}$ that is assigned to the C-O alcohol group stretch and a band at $1262 \mathrm{~cm}^{-1}$ of phenolic Aryl-O stretch. In the range of $1400-3600 \mathrm{~cm}^{-1}$, there are $\mathrm{C}=\mathrm{C}$ aromatic stretches $\left(1642\right.$ and $\left.1463 \mathrm{~cm}^{-1}\right)$, signals of saturated $\mathrm{C}-\mathrm{H}$ bonds $\left(2838\right.$ and $\left.2946 \mathrm{~cm}^{-1}\right)$, and a wide band centered at $3399 \mathrm{~cm}^{-1}$ that originated from the $\mathrm{O}-\mathrm{H}$ stretching, which belongs to alcohols and phenols. The dyes obtained with citric acid and $\mathrm{HCl}$ show very similar spectra, while the spectrum of the dye with TFA is distinguished mainly by a peak in $1716 \mathrm{~cm}^{-1}$ and a broad band between 550 and $800 \mathrm{~cm}^{-1}$; such signals for the other two cases appear as a shoulder and a peak defined at 719 and $619 \mathrm{~cm}^{-1}$, respectively. The bands due to $\mathrm{O}-\mathrm{H}$ and $\mathrm{C}-\mathrm{O}$ of phenolic type, together with $\mathrm{O}-\mathrm{H}$ of aromatic type are assigned to the aglyconic structure, while the bands of saturated $\mathrm{C}-\mathrm{H}$ and $\mathrm{O}-\mathrm{H}$ of alcohol belongs to the saccharide portion of the anthocyanins.

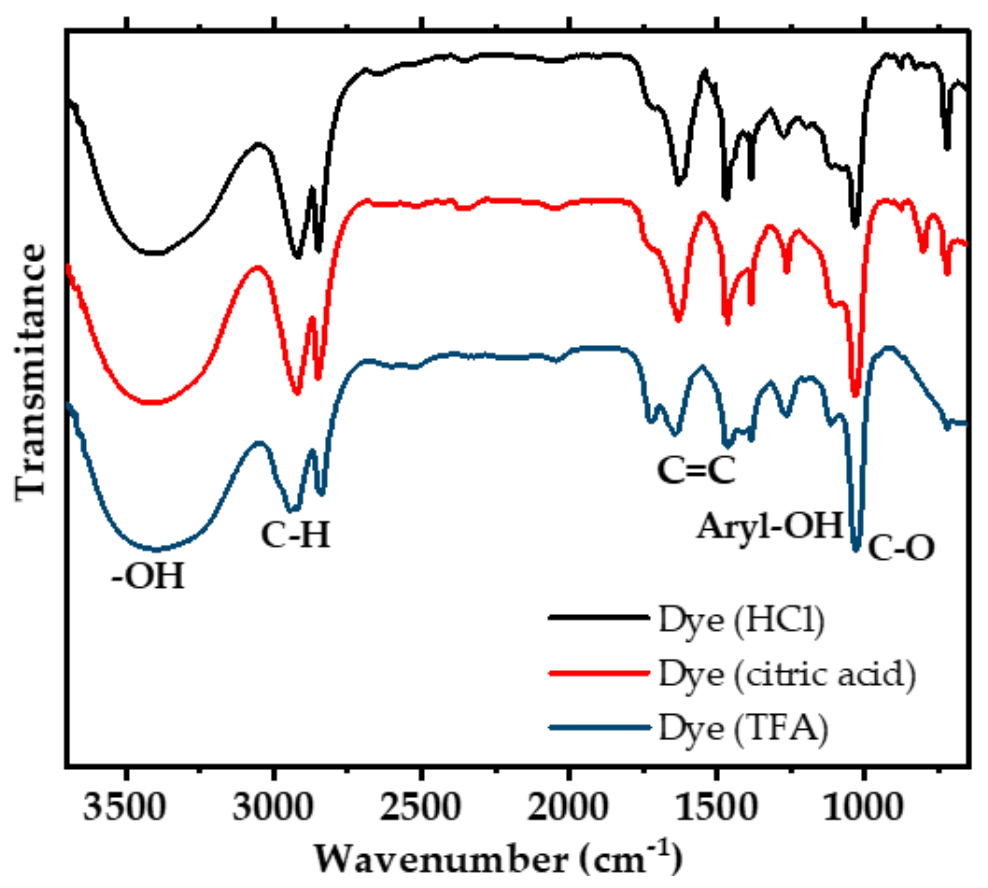

Figure 2. FT-IR spectra of purified anthocyanin extracts.

\subsection{High Performance Liquid Chromatography (HPLC)}

Chromatographic HPLC-DAD profiles of the dyes are shown in Figure 3. Seven main peaks were obtained between 22 and $37 \mathrm{~min}$, which are similar in each case. The peaks two (24.6 $\mathrm{min})$ and five $(27.7 \mathrm{~min})$ were predominant in all the extracts with similar intensities. In different chromatographic analyses of Vaccinium floribundum in reverse phase [20,21], it has been observed that delphinidin derivatives are characterized by having shorter retention times than their analogues cyanidin derivatives; where five anthocyanins have been found with the following order of elution: (1) delphinidin-3-galactoside (Dp-3-gl), (2) cyanidin-3-galactoside (Cy-3-gl), (3) delphinidin-3-arabinoside (Dp-3-ar), (4) Cy-3-gl, and (5) cyanidin-3-arabinoside (Cy-3-ar). These antecedents were useful for the identification in the extracts from mortiño dyes by comparison. In addition, the signs of the samples were compared with a standard of cyanidin, demonstrating the presence of this aglycone (peak 7) in all the extracts. 


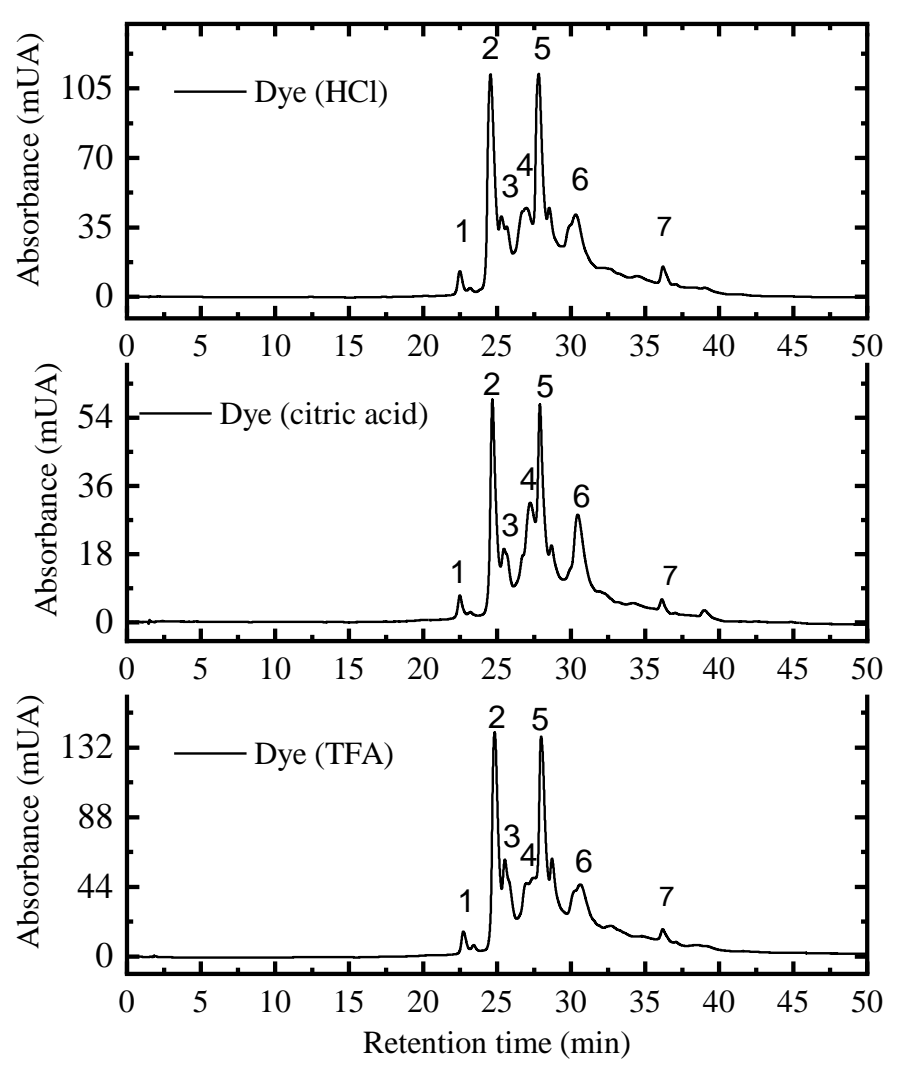

Figure 3. HPLC chromatographic profile of anthocyanins extracted with different acids from mortiño.

\subsection{Thin Layer Chromatography (TLC) + MALDI}

The combination of TLC and MALDI allowed identifying certain components in mortiño dye extracts. Colored fractions were separated using BAW eluent, resulting in four main fractions (A, B, C, and D), as can be seen in Figure 4a. The Rf values of fraction components were 0.32, 0.39, 0.51, and 0.86 respectively. Anthocyanins with a greater number of $-\mathrm{OH}$ groups will present a lower Rf since these reduce the mobility of the components as they are more affined to the stationary phase. This behavior has been observed and generalized in studies of TLC anthocyanins [37]. In this way, delphinidin derivatives are assigned to higher Rf than their equivalent cyanidines, since they differ by an $\mathrm{OH}$ group (delphinidin > cyanidin). The separated components were compared with a standard Cy-3-gl whose retention factor (0.44) differs from them, then the presence of Cy-3-gl was discarded. Figure 4 shows the reflectron mode MALDI mass spectra of B and C fraction, in both, one can observe a peak at $\mathrm{m} / \mathrm{z} 287$ corresponding to the cyanidin (aglycone) produced in the fragmentation of the anthocyanin, which was originally contained in both fractions. In the upper spectrum (b), a peak in $\mathrm{m} / \mathrm{z}$ 449 is also observed, indicating that the compound in fraction B is a hexoside of cyanidin. Similarly, in the lower spectrum (c), a peak at m/z 419 is assigned to fraction $C$ of cyanidin pentoside. According to [21], cyanidin hexosides can be found as Cy-3-gl and Cy-3-gal, while cyanidin pentoside can be found as Cy-3-ar; the anthocyanin corresponding to fraction B is assigned to Cy-3-gal. In addition, this was corroborated by discarding the means of the TLC standard test (Figure 4a). For the C fraction, the Cy-3-ar is assigned, since this is the only pentoside of cyanidin present in mortiño $V$. floribundum according to [20]. The chromatographic separation by TLC shows that the cyanidins 3-galactoside and 3 -arabinoside are the main dyes extracted and these correspond to the most intense peaks (2 and 5) of the HPLC chromatogram (Figure 3). 

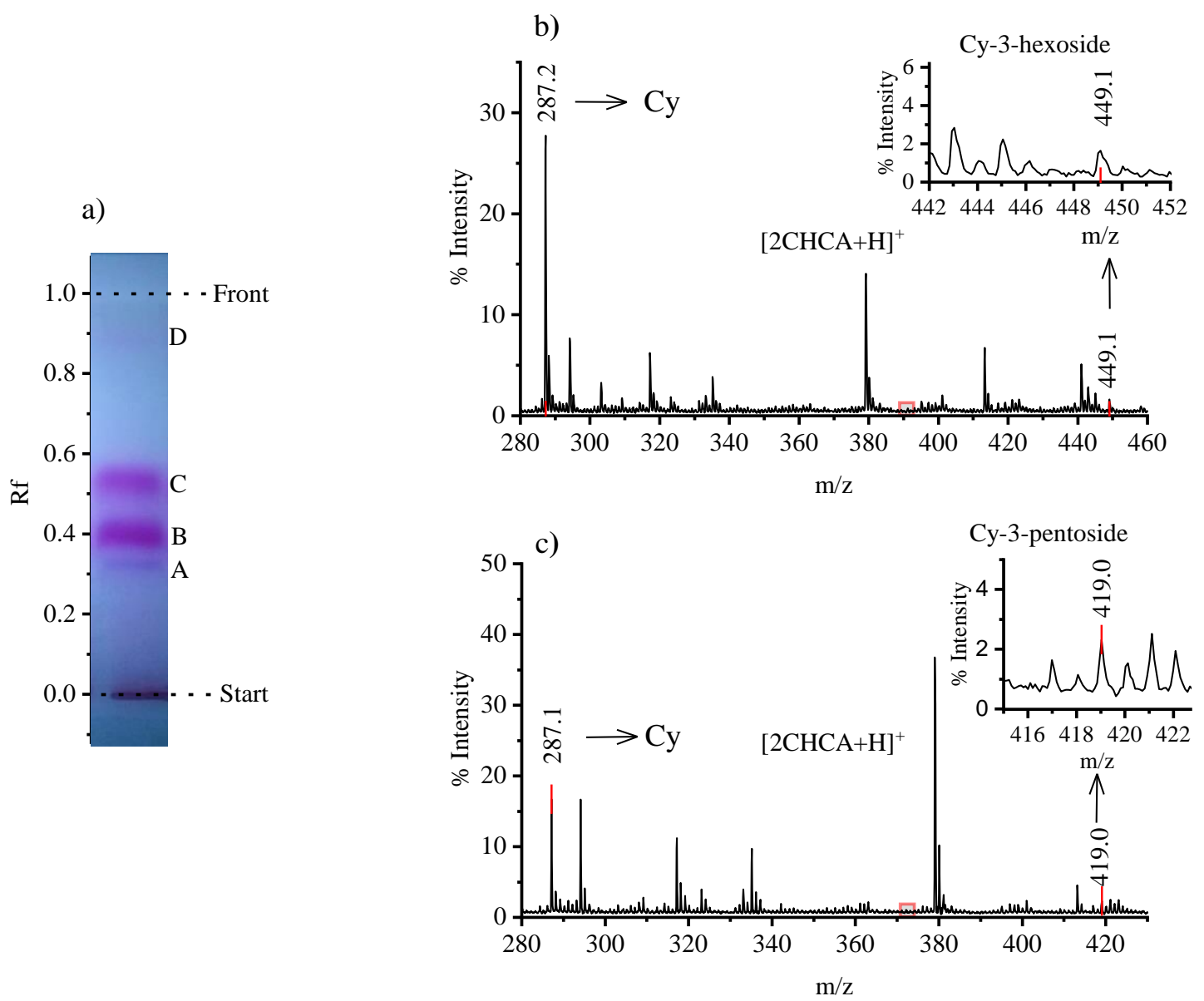

Figure 4. (a) Anthocyanins separated by TLC from mortiño extract (mobile phase: BAW 40:10:15, stationary phase: silica gel $\mathrm{F}_{270}$ ). MALDI spectra (CHCA matrix) of (b) cyanidin-3-hexoside and (c) cyanidin-3-pentoside fraction.

It is worth mentioning that the spectra of A and D TLC fractions did not show responses corresponding to any anthocyanin. These showed predominantly peaks of the CHCA matrix, thus it was not possible to assign their respective compounds. This difficulty probably arose since their unstable nature and the amount of compounds in these fractions were insufficient. Thus, they were not detected by MALDI under the working conditions.

\subsection{Characterization of DSSC}

Natural dyes extracted from mortiño with different acids were used as sensitizers of solar cells. The influence of acids on the performance of DSSC was studied through one-factor completely randomized design (acid of extraction) with six replicas. The J-V curves generated are shown in Figure 5, and the analyzed parameters through ANOVA are indicated in Table 1. 


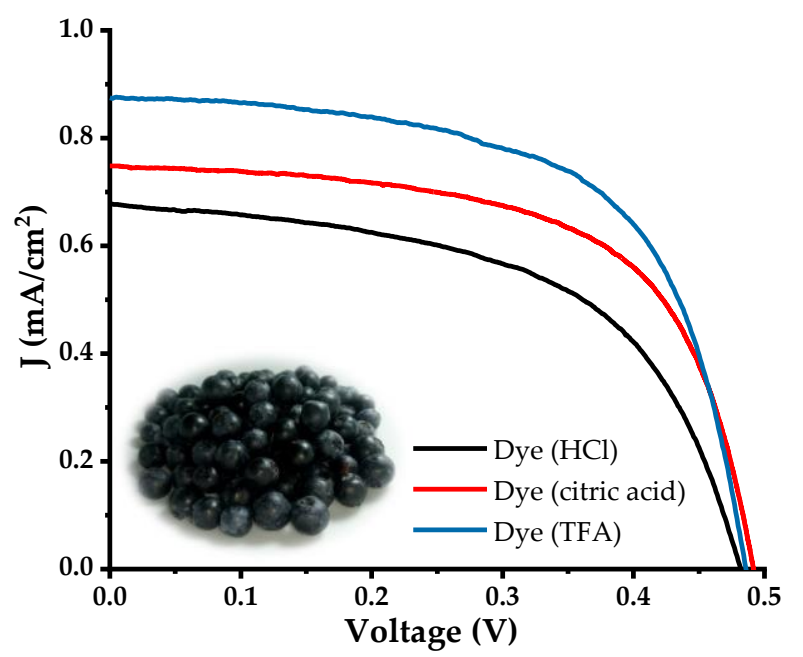

Figure 5. Average J-V curves of six DSSC with different extracts.

Table 1. Effect of different extraction acids on the photovoltaic parameters of the DSSC.

\begin{tabular}{ccccc}
\hline Extraction Acid & $\begin{array}{c}\text { Efficiency } \\
(\mathbf{\%} \boldsymbol{\eta})\end{array}$ & $\begin{array}{c}\text { JSC } \\
\left(\mathbf{m A} / \mathbf{c m}^{\mathbf{2}}\right)\end{array}$ & $\begin{array}{c}\mathbf{V}_{\mathbf{O C}} \\
\mathbf{( V )}\end{array}$ & FF \\
\hline AC & $0.23 \pm 0.05^{\mathrm{a}, \mathrm{b}}$ & $0.75 \pm 0.15^{\mathrm{a}}$ & $0.490 \pm 0.007^{\mathrm{a}}$ & $0.62 \pm 0.03^{\mathrm{a}}$ \\
$\mathrm{HCl}$ & $0.18 \pm 0.03^{\mathrm{a}}$ & $0.68 \pm 0.20^{\mathrm{a}}$ & $0.475 \pm 0.012^{\mathrm{b}}$ & $0.57 \pm 0.06^{\mathrm{a}}$ \\
TFA & $0.26 \pm 0.05^{\mathrm{b}}$ & $0.88 \pm 0.17^{\mathrm{a}}$ & $0.485 \pm 0.007^{\mathrm{a}, \mathrm{b}}$ & $0.62 \pm 0.04^{\mathrm{a}}$ \\
ANOVA & 0.027 & 0.181 & 0.035 & 0.156 \\
P & & & &
\end{tabular}

Average values \pm standard deviation of six DSSC. In each column, values that do not share a letter are significantly different with a confidence level of 0.05 according to the multiple comparisons Tukey test. The parameters with $p \leq$ 0.05 show a significant difference. ${ }^{a, b}$ means that there is no significant difference between the variables, and ${ }^{a}$ or ${ }^{b}$ means that whether there is a significant difference between the variables.

The ANOVA test shows that the efficiency $(\eta)$ of DSSC is affected by the use of different acids in dye extraction. The differences are significant between the $\mathrm{HCl}$ and TFA, while citric acid does not give a significant difference. The highest efficiencies in solar cells belong to TFA and coincide with the dye extracts that have the highest amounts of anthocyanins, as can be seen in 3.1. The greater efficiencies achieved using the extract with TFA might be the result of the greater quantity of disposable anthocyanins to attach on $\mathrm{TiO}_{2}$, which would help to greater capture photons on the photoanode. In contrast, the lower efficiencies were obtained with $\mathrm{HCl}$, although the lowest anthocyanins content corresponds to citric acid. This disagreement suggests that DSSC performance not only depends on the concentration of dye, but also other characteristics such as the nature of acid in the extraction can affect the performance of DSSC. The best performance is shown when organic acids such as citric acid and TFA are in extraction medium. Those organic acids promote an improvement in the electrical contact of $\mathrm{TiO}_{2}$ by the addition of carboxylate groups that block recombination processes between $\mathrm{TiO}_{2}$ and $\mathrm{I}^{-} / \mathrm{I}_{3}^{-}$electrolyte and enhance JSC, which is similar to that which occurs in treatments with organic acids as co-adsorbents [12,38]. Parameters like short circuit current density (JSC), open circuit potential (VOC) and fill factor (FF) were determined, and their differences in DSSC performance are not considerable.

Chenopy et al. measured the transient absorption signal of cyanin-sensitized nanoparticles of $\mathrm{TiO}_{2}$ and $\mathrm{ZrO}_{2}$ and found that charge separation is observed only in $\mathrm{TiO}_{2}$. Comparing transient absorption of different species of $\mathrm{TiO}_{2}$-cyannin, they assigned the transient absorption to excited electrons in the conduction band of $\mathrm{TiO}_{2}$ [23]. DFT calculations show that electron injection from an anthocyanin molecule to the $\mathrm{TiO}_{2}$ conduction band should be high because: (1) The energy level of the excited state of the dye lies above the conduction band of the semiconductor and this promotes the driving force for 
electron injection; (2) the rate constant of the electron injection from the dye to the $\mathrm{TiO}_{2}$ conduction band is high, which increases the power conversion efficiency; (3) the light-harvesting efficiency is good enough to maximize the photocurrent response; and (4) the dye-electrolyte regeneration energy is negative, inducing the driving force for dye regeneration. [39,40].

\section{Conclusions}

Dyes extracted from mortiño fruits were used as sensitizers in DSSC and were characterized by chromatography (HPLC and TLC), FT-IR spectroscopy and MALDI mass spectrometry analysis. The most abundant compounds in mortiño extracts correspond to cyanidin derivate anthocyanins. Mortiño dye-sensitized solar cells have a power conversion efficiency between $0.18-0.26 \%$, which is influenced significantly by the acid extraction medium. In this work, the maximum value is obtained using the TFA-acidified methanol.

Further studies of anthocyanins from mortiño dyes and other natural sources are required in order to identify which component gives the best performance. In addition, it is necessary to study factors such as interactions between compounds in the extract dyes (e.g., concentration, co-adsorption and dye aggregated) that would influence the efficiency of a DSSC.

Author Contributions: Conceptualization, P.J.E.-M. and C.P.S.; methodology, M.A.T.-U., P.J.E.-M. and C.P.S.; software, P.J.E.-M. and C.P.S.; validation, M.A.T.-U., P.J.E.-M. and C.P.S.; formal analysis C.P.S.; investigation, M.A.T.-U., P.J.E.-M. and C.P.S.; resources, M.A.T.-U., P.J.E.-M. and C.P.S.; data curation, P.J.E.-M. and C.P.S.; writing-original draft preparation, M.A.T.-U. and P.J.E.-M.; writing—review and editing, P.J.E.-M. and C.P.S.; visualization, P.J.E.-M. and C.P.S.; supervision, P.J.E.-M. and C.P.S.; project administration, C.P.S.; funding acquisition, P.J.E.-M. and C.P.S. All authors have read and agreed to the published version of the manuscript.

Funding: This research was funded by EPN for funding through the PIMI 14-08 research project.

Acknowledgments: The authors acknowledge to: Pablo Bonilla from Universidad Central del Ecuador for technical support in UV-Vis and HPLC, Cristina Calero and Paco Noriega from Universidad Politécnica Salesiana for supporting in DSSC construction and TLC test, respectively.

Conflicts of Interest: The authors declare no conflict of interest.

\section{References}

1. International Energy Agency. $\mathrm{CO}_{2}$ Emissions from Fuel Combustion Highlights. 2017. Available online: http: //www.indiaenvironmentportal.org.in/files/file/CO2EmissionsfromFuelCombustionHighlights2017.pdf (accessed on 21 January 2020).

2. Babayigit, A.; Ethirajan, A.; Muller, M.; Conings, B. Toxicity of organometal halide perovskite solar cells. Nat. Mater. 2016, 15, 247-251. [CrossRef] [PubMed]

3. Hsu, D.D.; O’Donoughue, P.; Fthenakis, V.; Heath, G.A.; Kim, H.C.; Sawyer, P.; Choi, J.K.; Turney, D.E. Life Cycle Greenhouse Gas Emissions of Crystalline Silicon Photovoltaic Electricity Generation. J. Ind. Ecol. 2012, 16, S122-S135. [CrossRef]

4. Tsoutsos, T.; Frantzeskaki, N.; Gekas, V. Environmental impacts from the solar energy technologies. Energy Policy 2005, 33, 289-296. [CrossRef]

5. Grätzel, M. Dye-sensitized solar cells. J. Photochem. Photobiol. C Photochem. Rev. 2003, 4, 145-153. [CrossRef]

6. Gong, J.; Sumathy, K.; Qiao, Q.; Zhou, Z. Review on dye-sensitized solar cells (DSSCs): Advanced techniques and research trends. Renew. Sustain. Energy Rev. 2017, 68, 234-246. [CrossRef]

7. Bagher, A.M. Introduction to Natural Dye Sensitized Solar Cells. Eng. Phys. 2017, 1, 1-7.

8. Clifford, J.N.; Martínez-Ferrero, E.; Viterisi, A.; Palomares, E. Sensitizer molecular structure-device efficiency relationship in dye sensitized solar cells. Chem. Soc. Rev. 2011, 40, 1635-1646. [CrossRef]

9. Wang, P.; Klein, C.; Humphry-Baker, R.; Zakeeruddin, S.M.; Grätzel, M. A High Molar Extinction Coefficient Sensitizer for Stable Dye-Sensitized Solar Cells. J. Am. Chem. Soc. 2005, 127, 808-809. [CrossRef]

10. Wongcharee, K.; Meeyoo, V.; Chavadej, S. Dye-sensitized solar cell using natural dyes extracted from rosella and blue pea flowers. Sol. Energy Mater. Sol. Cells 2005, 91, 566-571. [CrossRef] 
11. Ludin, N.A.; Mahmoud, A.M.A.A.; Mohamad, A.B.; Kadhum, A.A.H.; Sopian, K.; Karim, N.S.A. Review on the development of natural dye photosensitizer for dye-sensitized solar cells. Renew. Sustain. Energy Rev. 2014, 31, 386-396. [CrossRef]

12. Calogero, G.; Yum, J.H.; Sinopoli, A.; Di Marco, G.; Grätzel, M.; Nazeeruddin, M.K. Anthocyanins and betalains as light-harvesting pigments for dye-sensitized solar cells. Sol. Energy 2012, 86, 1563-1575. [CrossRef]

13. Calogero, G.; Di Marco, G. Red Sicilian orange and purple eggplant fruits as natural sensitizers for dye-sensitized solar cells. Sol. Energy Mater. Sol. Cells 2008, 92, 1341-1346. [CrossRef]

14. San Esteban, A.C.M.; Enriquez, E.P. Graphene-anthocyanin mixture as photosensitizer for dye-sensitized solar cell. Sol. Energy 2013, 98, 392-399. [CrossRef]

15. Nan, H.; Shen, H.P.; Wang, G.; Xie, S.D.; Yang, G.J.; Lin, H. Studies on the optical and photoelectric properties of anthocyanin and chlorophyll as natural co-sensitizers in dye sensitized solar cell. Opt. Mater. 2017, 73, 172-178. [CrossRef]

16. Teoli, F.; Lucioli, S.; Nota, P.; Frattarelli, A.; Matteocci, F.; Di Carlo, A.; Caboni, E.; Forni, C. Role of pH and pigment concentration for natural dye-sensitized solar cells treated with anthocyanin extracts of common fruits. J. Photochem. Photobiol. A Chem. 2017, 316, 24-30. [CrossRef]

17. Homeier, J.; Werner, F.A.; Gradstein, S.R.; Breckle, S.W.; Richter, M. Flora and Fungi: Composition and Function BT-Gradients in a Tropical Mountain Ecosystem of Ecuador; Beck, E., Bendix, J., Kottke, I., Makeschin, F., Mosandl, R., Eds.; Springer: Berlin/Heidelberg, Germany, 2008; pp. 87-100.

18. Council, N.R. Lost Crops of the Incas: Little-Known Plants of the Andes with Promise for Worldwide Cultivation; National Academies Press: Washington, DC, USA, 1989.

19. Solarte, C.U. Patrimonio Cultural Alimentario; Fondo Editorial Ministerio de Cultura: Quito, Ecuador, 2010.

20. Vasco, C.; Riihinen, K.; Ruales, J.; Kamal-Eldin, A. Chemical Composition and Phenolic Compound Profile of Mortiño (Vaccinium floribundum Kunth). J. Agric. Food Chem. 2009, 57, 8274-8281. [CrossRef]

21. Schreckinger, M.E.; Wang, J.; Yousef, G.; Lila, M.A.; De Mejia, E.G. Antioxidant Capacity and in Vitro Inhibition of Adipogenesis and Inflammation by Phenolic Extracts of Vaccinium floribundum and Aristotelia chilensis. J. Agric. Food Chem. 2010, 58, 8966-8976. [CrossRef]

22. Vizuete, K.S.; Kumar, B.; Vaca, A.V.; Debut, A.; Cumbal, L. Mortiño (Vaccinium floribundum Kunth) berry assisted green synthesis and photocatalytic performance of Silver-Graphene nanocomposite. J. Photochem. Photobiol. A Chem. 2016, 329, 273-279. [CrossRef]

23. Cherepy, N.J.; Smestad, G.P.; Grätzel, M.; Zhang, J.Z. Ultrafast Electron Injection: Implications for a Photoelectrochemical Cell Utilizing an Anthocyanin Dye-Sensitized $\mathrm{TiO}_{2}$ Nanocrystalline Electrode. J. Phys. Chem. B 1997, 101, 9342-9351. [CrossRef]

24. Chien, C.Y.; Hsu, B.D. Optimization of the dye-sensitized solar cell with anthocyanin as photosensitizer. Sol. Energy 2013, 98, 203-211. [CrossRef]

25. Ramamoorthy, R.; Radha, N.; Maheswari, G.; Anandan, S.; Manoharan, S.; Williams, R.V. Betalain and anthocyanin dye-sensitized solar cells. J. Appl. Electrochem. 2016, 46, 929-941. [CrossRef]

26. Zolkepli, Z.; Lim, A.; Ekanayake, P.; Tennakoon, K. Efficiency Enhancement of Cocktail Dye of Ixora coccinea and Tradescantia spathacea in DSSC. J. Biophys. 2015, 2015, 582091. [CrossRef] [PubMed]

27. Strauch, R.C.; Mengist, M.F.; Pan, K.; Yousef, G.G.; Iorizzo, M.; Brown, A.F.; Lila, M.A. Variation in anthocyanin profiles of 27 genotypes of red cabbage over two growing seasons. Food Chem. 2019, 301, 125289. [CrossRef] [PubMed]

28. Lee, J.; Durst, R.; Wrolstad, R. Determination of total monomeric anthocyanin pigment content of fruit juices, beverages, natural colorants, and wines by the $\mathrm{pH}$ differential method: Collaborative Study. J. AOAC Int. 2005, 88, 1269-1278. [CrossRef] [PubMed]

29. Rodriguez-Saona, L.E.; Wrolstad, R.E. Extraction, Isolation, and Purification of Anthocyanins. Curr. Protoc. Food Anal. Chem. 2001. [CrossRef]

30. Durst, R.W.; Wrolstad, R.E. Separation and Characterization of Anthocyanins by HPLC. Curr. Protoc. Food Anal. Chem. 2001. [CrossRef]

31. Santacruz, C.P.; Håkansson, P.; Barofsky, D.F.; Piyadasa, C.K.G. A Constant-Momentum/Energy-Selector Time-of-Flight Mass Spectrometer. J. Am. Soc. Mass Spectrom. 2007, 18, 92-101. [CrossRef]

32. Siegelman, H.W.; Hendricks, S.B. Photocontrol of Alcohol, Aldehyde, and Anthocyanin Production in Apple Skin. Plant Physiol. 1958, 33, 409-413. [CrossRef] 
33. Giusti, M.M.; Wrolstad, R.E. Characterization and Measurement of Anthocyanins by UV-Visible Spectroscopy. Curr. Protoc. Food Anal. Chem. 2001. [CrossRef]

34. Harborne, J.B. Spectral methods of characterizing anthocyanins. Biochem. J. 1958, 70, 22-28. [CrossRef]

35. Fernando, J.M.R.C.; Senadeera, G.K.R. Natural anthocyanins as photosensitizers for dye-sensitized solar devices. Curr. Sci. 2008, 95, 663-666.

36. Hao, S.; Wu, J.; Huang, Y.; Lin, J. Natural dyes as photosensitizers for dye-sensitized solar cell. Sol. Energy 2006, 80, 209-214. [CrossRef]

37. Jackman, R.L.; Yada, R.Y.; Tung, M.A. A review: Separation and chemival properties of anthocyanins used for their qualitative and quantitative analysys. J. Food Biochem. 1987, 11, 279-308. [CrossRef]

38. Murayama, M.; Mori, T. Equivalent Circuit Analysis of Dye-Sensitized Solar Cell by Using One-Diode Model: Effect of Carboxylic Acid Treatment of $\mathrm{TiO}_{2}$ Electrode. Jpn. J. Appl. Phys. 2006, 45, 542-545. [CrossRef]

39. Obasuyi, A.R.; Glossman-Mitnik, D.; Flores-Holguín, N. Electron injection in anthocyanidin and betalain dyes for dye-sensitized solar cells: A DFT approach. J. Comput. Electron. 2019, 18, 396-406. [CrossRef]

40. Lakshmanakumar, M.; Sriram, S.; Balamurugan, D. Performance analysis of $\mathrm{TiO}_{2}$ flavylium compound-based dye-sensitized solar cell (DSSC): A DFT-TDDFT approach. J. Comput. Electron. 2018, 17, 1143-1152. [CrossRef]

(C) 2020 by the authors. Licensee MDPI, Basel, Switzerland. This article is an open access article distributed under the terms and conditions of the Creative Commons Attribution (CC BY) license (http://creativecommons.org/licenses/by/4.0/). 